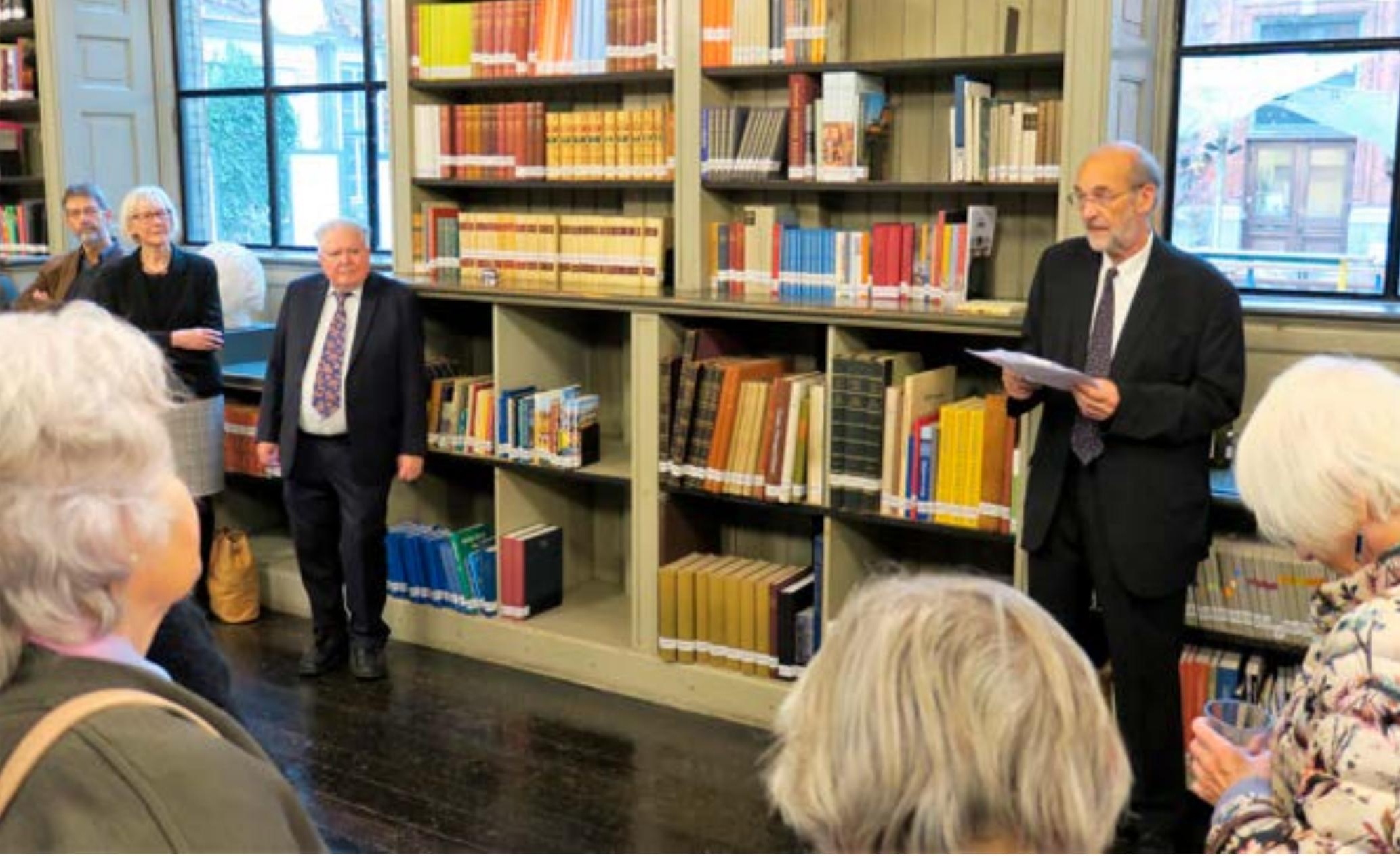

\title{
En grundvold i demokratiet
}

Biblioteker for de få. Biblioteker for alle. Det er undertitlen på Dansk Bibliotekshistorie. REVY var med til lanceringen af tobindsværket, der fortæller om danske biblioteker i deres mangfoldighed.

\section{- Det er en fantastisk dag!}

Den 2. november kunne Bente Kaspersen fra Dansk Bibliotekshistorisk Selskab stolt præsentere Dansk Bibliotekshistorie. De to tykke bind dækker udviklingen fra middelalderens samlinger af håndskrifter til den digitale tidsalder med nye udfordringer til alle biblioteker og informationscentre.

- Værket beskriver det danske biblioteksvæsen, som er internationalt kendt. Det er blevet inspireret af andre landes bibliotekstanker - og mange lande bruger danske biblioteker som målestok for udvikling af deres eget biblioteksvæsen, forklarer Bente Kaspersen de mange fremmødte.
Lanceringen skete i den smukke sal i Danmarks Kunstbibliotek på Charlottenborg med bøger i flere etager, Danmarks ældste læsesal, der stadig er i brug.

\section{Saxo fik den første hjemkaldelse}

De to tykke bind er fyldt med gode historier, som da Saxo af Absalon i 1201 blev pålagt at levere to bøger tilbage til Vor Frue Kloster i Sorø, den første hjemkaldelse i Danmark.

Om bøger, der blev lænket fast til reolerne i middelalderens biblioteker, for skrifterne var meget kostbare. På Nationalmuseet opbevares i dag lænkede bøger fra Kalundborg Kirke.
Tekst og foto: Jan Kjær,

Better-World.dk
Der er også meget at dykke ned i for læsere med interesse for Forsknings-, Fag- og Uddannelsesbiblioteker.

I bind 1 beskrives eksempelvis, hvordan Universitetsbiblioteket blev grundlagt i 1482.

- Det bestod i begyndelsen blot af nogle få håndskrifter og havde til huse i et kapel i Vor Frue Kirke. Det voksede hurtigt, specielt efter bogtrykkerkunsten mangedoblede bogproduktion. Efter 1530 flyttede biblioteket til Helligåndshuset, som var en del af et nedlagt kloster. Bygningen eksisterer stadig og er en af Københavns ældste middelalderbygninger. 


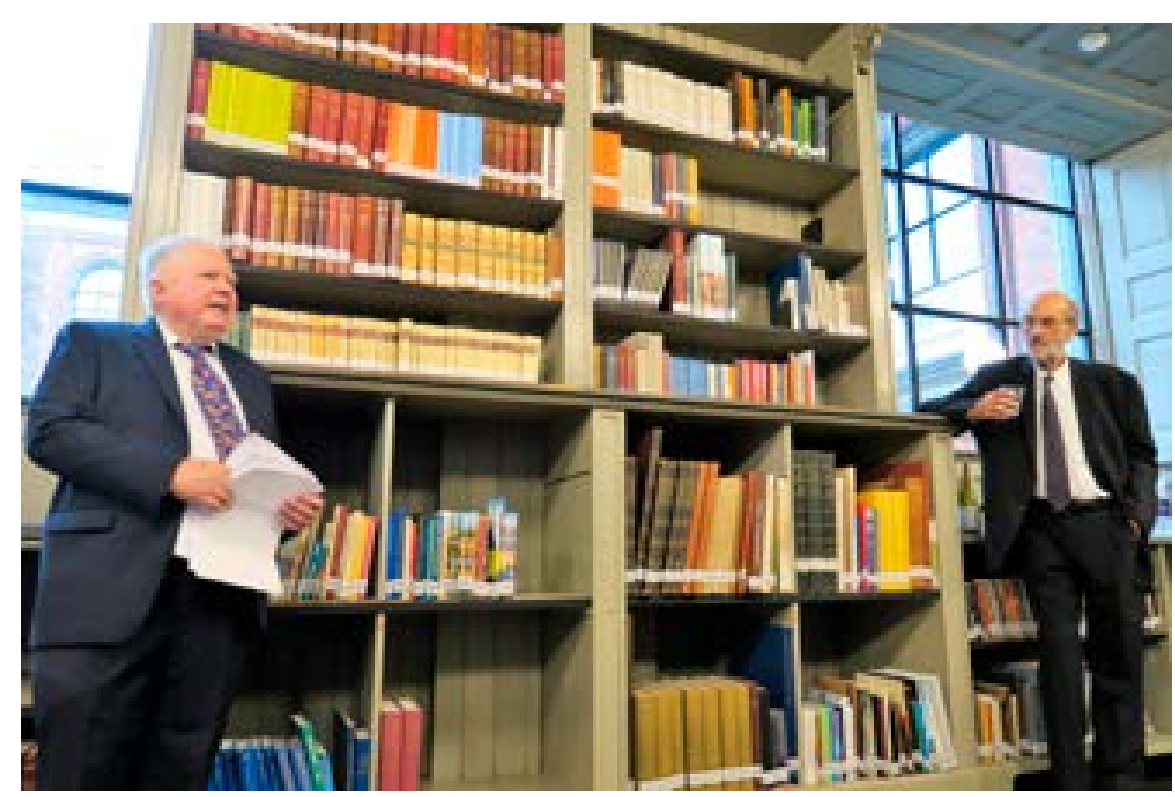

En stolt Steen Bille Larsen (tv) præsenterer i november 2021 resultatet af fem mands arbejde: værket Dansk Bibliotekshistorie - spækket med oplysninger, anekdoter og illustrationer om biblioteksvæsenets tilblivelse. Det er medredaktør Nan Dahlkild til højre.

Det ligger i dag på Strøget i København.

\section{Coronaen forsinkede arbejdet}

Nan Dahlkild og Steen Bille Larsen fik af Dansk Bibliotekshistorisk Selskab først opgaven som tovholdere og senere redaktører.

- Med de to vidste vi, at opgaven med at skrive Dansk Bibliotekshistorie var i gode hænder. De har arbejdet systematisk og ikke ladet sig distrahere af alle forhindringerne undervejs, forklarer Bente Kaspersen.

Og forhindringer har der været mange af.

Idéen blev undfanget i 2016, økonomien faldt på plads i 2018, og lanceringen skulle være sket i 2020, 100-året for Danmarks første bibliotekslov, men Corona-pandemien betød, at biblioteker lukkede, og adgangen til kilder blev besværliggjort.

\section{Bibliotekerne er ingen selvfølge} Både ved lanceringen og i selve værket pointeres sammenhængen mellem biblioteker og demokratiet.

- Adgang til og distribution af information er jo grundvold i demokratiet. Derfor er bibliotekerne så vigtige i en demokratisk udvikling, siger Bente Kaspersen og fortsætter:

- Såvel førhen som i dag er der biblioteker, der bliver begrænset eller lukket, fordi det støder nogle magthavere.

I Dansk Bibliotekshistories sidste kapitel 'Næsten eventyrlige, men ingen selvfølge' opsummeres de udfordringer, som bibliotekerne står over for.

\section{- Bibliotekernes situation er ikke} omgærdet af samme optimisme som tidligere. Biblioteksbegrebet er både udvidet og udfordret. Store institutioner har skiftet navn og indhold. I den offentlige debat er bibliotekerne blevet kaldt overflødige. Til gengæld har kampen mod lukningen af biblioteksfilialer udløst folkelige energier som i bogsamlingsbevægelsens pionerdage: De vil ikke dø.
- Bibliotekerne er ligesom demokratiet ikke nogen selvfølge, og ligesom demokratiets fremtid afhænger af den folkelige deltagelse, vil bibliotekernes fremtid blive bestemt af deres brug og brugere. Bibliotekerne har altid været og vil fortsat være under forandring. De er stadig mulighedernes rum.

Læs også interview med redaktørerne på næste side. Boganmeldelse følger i næste nummer af REVY.

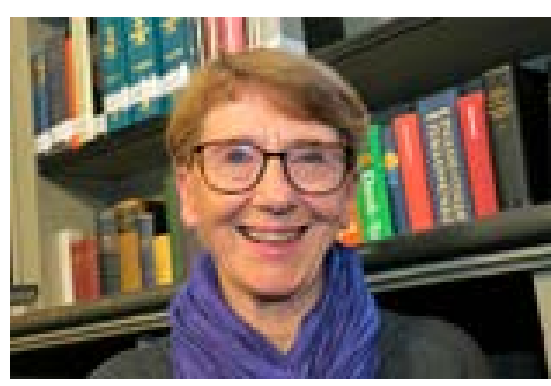

- Adgang til og distribution af information er jo grundvold i demokratiet. Derfor er bibliotekerne så vigtige i en demokratisk udvikling, siger Bente Kaspersen fra Dansk Bibliotekshistorisk Selskab. 


\section{0 sider i en Maggi-terning}

- både om privat- folke- og forskningsbiblioteker

\section{Bind 1}

Biblioteker for de få begynder sin næsten tusinde år lange fortælling med biblioteker i kirker og klostre, der var forbeholdt præster og skriftkloge munke som historikeren Saxo, der i 1200-tallet benyttede biskop Absalons bibliotek til at skrive sin Danmarkskrønike. Efter reformationen i 1536 skabte konger, adelige og lærde deres egne biblioteker, men stadig med adgang for ganske få, for bøger var kostbare.

I 1700-tallets oplysningstid oprettede borgerskabet læseforeninger og lejebiblioteker i byerne, mens folk på landet måtte klare sig med beskedne almue- og sognebiblioteker. Store nationale biblioteker voksede samtidig frem med enestående samlinger af bøger og håndskrifter.

Det Kongelige Bibliotek blev åbnet for offentligheden i 1793, så samlingerne kunne udnyttes til videnskabelige formål. Nye klasser, nye fællesskaber og nye biblioteker dukkede op.

Omkring år 1900 oprettede bogsamlingsbevægelsen samlinger både i byerne og på landet.

\section{Bind 2}

Biblioteker for alle har som udgangspunkt biblioteksloven fra 1920, der åbnede for statslig støtte til kommuner med biblioteker med oplysende formål. Målet var at nå ud til alle landets borgere for at bidrage til et demokratisk og oplyst samfund.

Med den vigtige ændring af biblioteksloven i 1964 kunne bibliotekerne inddrage nye lyd-og billedmedier og tage initiativ til flere kulturelle arrangementer.

Forskningsbibliotekerne åbnede sig for et voksende antal forskere og studerende fra 1960'erne og frem, og stadig flere specialiserede og faglige biblioteker kom til.

Digitaliseringen har forbedret søgemulighederne i forhold til både historisk og helt aktuelt materiale, og samarbejdet mellem folke- og forskningsbiblioteker har gjort information mere tilgængelig for alle.

Bind 2 afrundes med debatten om bibliotekernes fremtidige muligheder og ændrede vilkår i det 21. århundrede domineret af sociale medier, nem adgang til information via nettet, ændrede udlånsmønstre, stigende besøgstal og øgede kulturelle aktiviteter.

\section{Danmarks første bevarede hjemkaldelse}

Kort før sin død i 1201 udfærdigede Absalon et udførligt testamente, hvor også Saxo blev betænkt, dog mest med formaninger: "Sin klerk Saxo overlod han de $2 \frac{1}{2}$ mark sølv, som han havde givet ham. Saxo er forpligtet til at tilbagelevere Sorø Kloster de to bøger, ærkebiskoppen havde overladt ham." (1. bind side 38)

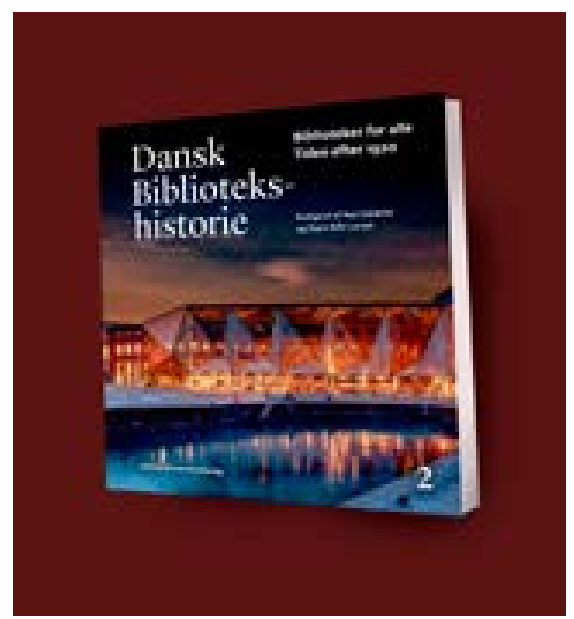

DANSK BIBLIOTEKSHISTORIE 1-2

ISBN 9788771845136

Aarhus Universitetsforlag

Udgivet i 1.000 eksemplarer

790 SIDER PRIS 495 KR. 